\section{First experimental evidence for magmatic crystallization of bastnaesite and burbankite}

\section{ANNA NIKOLENKO, PHD ${ }^{1,2,3}$, KONSTANTIN STEPANOV $^{3}$ AND ILYA V. VEKSLER ${ }^{3,4}$}

${ }^{1}$ Helmholtz Centre Potsdam - German Research Centre for Geosciences GFZ

${ }^{2}$ Potsdam University

${ }^{3}$ V.S. Sobolev Institute of Geology and Mineralogy SB RAS

${ }^{4}$ GFZ German Research Centre for Geosciences

Presenting Author: nikolenko@uni-potsdam.de

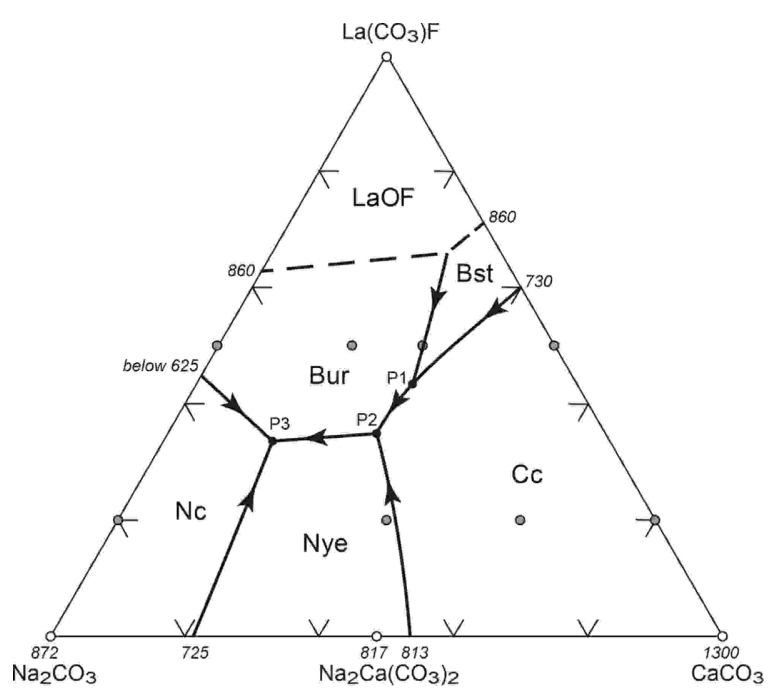

Bastnaesite $\left[\operatorname{REE}\left(\mathrm{CO}_{3}\right) \mathrm{F}\right]$ is the main mineral of rare earth ore deposits in carbonatites. Synthetic analogues of bastnaesite have been precipitated from aqueous solutions by many different methods. However, previous attempts to model magmatic crystallization of bastnaesite in the system $\mathrm{La}(\mathrm{OH})_{3}-\mathrm{Ca}(\mathrm{OH})_{2}$ $\mathrm{CaCO}_{3}$ (Jones and Wyllie, 1986) were unsuccessful. Here we present the first experimental evidence for magmatic crystallization of bastnaesite and some other REE carbonates in the model system $\mathrm{La}\left(\mathrm{CO}_{3}\right) \mathrm{F}-\mathrm{CaCO}_{3}-\mathrm{Na}_{2} \mathrm{CO}_{3}$ at $100 \mathrm{MPa}$ and temperatures between 625 and $850{ }^{\circ} \mathrm{C}$.

Our experiments on mixtures of reagent-grade $\mathrm{CaCO}_{3}$, $\mathrm{Na}_{2} \mathrm{CO}_{3}, \mathrm{La}_{2}\left(\mathrm{CO}_{3}\right)_{3}$ and $\mathrm{LaF}_{3}$ were carried out in cold-seal rapidquench pressure vessels. Positions of the starting compositions on T-x phase diagram (see the figure) are shown by grey circles. Carbon dioxide and fluorine were found to behave as independent components and, therefore, the system is pseudoternary. The liquidus phases are calcite $(\mathrm{Cc})$, nyerereite (Nye), natrite ( $\mathrm{Nc}$ ), bastnaesite (Bst) and burbankite solid solution (Bur). Sodium-lanthanum fluorcarbonate analogous to arisite appeared in one run in sub-liquidus at $625{ }^{\circ} \mathrm{C}$. Calcite, bastnaesite and burbankite solid solution $(\mathrm{Na}, \mathrm{Ca})_{3}(\mathrm{Ca}, \mathrm{La})_{3}\left(\mathrm{CO}_{3}\right)_{5}$ are involved in a peritectic reaction which corresponds to the piercing point $\mathrm{P} 1$ on the liquidus surface. There are at least two other piercing points (P2) and (P3) which are probably pseudoeutectics (local temperature minima).

The solubility of $\mathrm{La}_{2} \mathrm{O}_{3}$ in melts saturated in calcite and bastnaesite decreases from 44 to 20 wt.\% with falling temperature and in parallel with increasing $\mathrm{Na} / \mathrm{Ca}$ in the evolving liquid. The solubility is so high that it is hardly reachable by REE in natural carbonatite magmas. In nature, the REE solubility is probably controlled by phosphates (apatite and monazite) and $\mathrm{Nb}$-Ti minerals of the perovskite and pyrochlore groups. Thus, despite the stability of bastnaesite and burbankite in the model system, it remains unclear whether they can crystallize in carbonatites as primary magmatic minerals. Answering this question would require experiments on compositions containing $\mathrm{P}_{2} \mathrm{O}_{5}$ and $\mathrm{TiO}_{2}$ that we are planning in the future.

This study was supported by RSF grant № 19-17-00013.

References

Jones, A. and Wyllie, P. (1986) Applied Geochemistry, 1, 95102. 